\title{
Growth performance and carcass characteristics of finisher broiler chickens fed diet containing cooked cocoyam tubermeal \\ ${ }^{1}$ Anyaegbu, B. C., ${ }^{* 1}$ Onunkwo, D. N., ${ }^{2}$ Igwe, G., ${ }^{1}$ Nathaniel, J. and ${ }^{1}$ Nkwo, C. M. \\ ${ }^{\prime}$ College of Animal Science and Animal Production, \\ ${ }^{2}$ College of Veterinary Medicine,

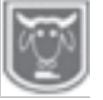 \\ Michael Okpara University of Agriculture, Umudike, \\ Umuahia, Abia State, Nigeria \\ Abstract \\ *Corresponding author: donunkwo1@gmail.com; +2348033388622
}

This study was carried out to evaluate the growth performance and carcass characteristics of finisher broiler chickens fed diet containing cooked cocoyam tubermeal as energy source in place of maize. The proximate composition of cooked cocoyam tubermeal showed that it contained $13.11 \%$ moisture, $2.60 \%$ ash, $3.90 \%$ crude protein, $9.45 \%$ crude fiber, $1.85 \%$ ether extract and $70.13 \%$ NFE. In the finisher feeding trial, the cooked cocoyam tubermeal was used to replace maize at levels of 25\%, 50\%, 75\% and 100\% respectively in the control diet. Each finisher diet was fed to a group of 30 finisher broiler chicken for 4 weeks using completely randomized design. Each treatment was divided into 3 replicates of 10 broiler chicks each. The birds were kept on deep litter and were given feed and water ad-libitum. Parameters measured include ifinal body weight, body weight gain feed intake, feed conversion ratio, carcass characteristics and economics of production. In the finisher feeding trial, the feed intake of the finisher broilers on diets 2, 3 and 4 were similar and compared favourably with those on the control diet. The finisher group on 100\% CCYM (diet 5) recorded the lowest feed intake possibly because of the dustiness of the feed. The body weight gain of the finisher broilers on diet $2(25 \%)$ cooked cocoyam tubermeal compared favourably with the control group and was significantly $(P<0.05)$ higher than those on other diets. It appeared that the finisher broilers could not tolerate high levels of cooked cocoyam meal due to dustiness of the feed and its anti-nutritional factors. The cost of production per $\mathrm{kg}$ finisher broilers was cheapest for diet 5(100\% CCYM) (N356.72) and the costliest was for diet 3(50\% CCYM) (N588.28). The internal organs expressed as percent of the live weight were not affected by the treatments. In terms of carcass characteristics, the finisher broilers on diet 2(25\% CCYM) recorded the highest breast muscle which was significantly different $(P<0.05)$ from other groups. There were no significant different $(P>0.05)$ on percent back cut, drumstick, head, shank, thigh, neck and wings of the finisher broilers on all the treatments. There were no significant differences $(P>0.05)$ in percent dressed weight of the finisher broilers on cooked cocoyam based diets. The results of the trial have shown that cooking cocoyam corms (Xanthosoma sagittifolium) for 30 minutes was effective for reducing the cyanide oxalate, tannin, phytic acid and saponin content and that cooking did not affect the proximate composition of tannia. Cooked cocoyam tubermeal could be used to replace maize up to $25 \%$ in the diet of finisher broiler chicken without affecting body weight gain, feed intake and feed conversion ratio as indicated in this study.

Keywords: Nutritional evaluation, cooked cocoyam, growth performance, carcass characteristics, finisher broilers.

\section{Introduction}

Feed is the major component of the total cost of production for meat and egg production in poultry industry. Maize constitutes the bulk of the energy source used in compounding concentrate rations. Other grains used but to a lesser extent include sorghum, millet, wheat, barley and 


\section{Growth performance and carcass characteristics of finisher broiler chickens}

oats. Maize supplies the bulk energy in animal feed especially for poultry. It is currently expensive and scarce due to low production and higher consumption rates by man. Maize is also put into numerous industrial uses including production of agro fuels (Obasi, 2009; Adeola and Olukosi, 2009), thus diverting maize away from man and animal food chain and this has led to increase in the cost of maize and consequently increase in the cost of poultry feed which is reflected in the high cost of poultry production., In other to ameliorate this problem, alternative sources of energy feedstuffs that are less in demand with relatively lower cost must be exploited.

Besides, depending on maize alone as the sole source of dietary energy may be devastating to poultry production, because of the frequent drought and locust attack affecting some maize producing areas (Agwunobi and Essien, 1995). Therefore, there is need for continued and consistent search for alternative source of energy that is cheap when compared to maize that could take the place of maize in poultry ration formulation. Cocoyam products are recognized as cheaper carbohydrate sources than grains or other tuber crops. Thus, tannia cocoyam (Xanthosoma sagittifoilum) is a non-conventional feedstuff that provides readily available energy with easily digestible carbohydrate. Xanthosoma sagittifoilum is readily found in all hot and humid areas of the world as is cultivated extensively throughout West Africa (Onwueme, 1982). It was suggested that tannia cocoyam are now more important than taro cocoyam (Colocasia esculenta) being more popular (FAO, 1990) due to superiority of their corms and cormels in terms of energy, proteins and mineral elements (Mwenye, 2009). The nutritional quality of cocoyam compares favourably with cassava, potatoes and yam (Bello, 1976). Xanthosoma sagittifoilum is a high yielding, disease resistant crop. It is almost competition free with man in most places as it is eaten only as a last resort when a family can no longer afford garri or yam. It is therefore more likely to be available for use at lower cost. The substitution of grains with roots and tubers is an economical question, and roots have a great potential in many areas of the world as a major supplier of energy for animals (Gohl, 1975). Although, the root and tuber meals are low in protein, its energy content is remarkably high and its price relative to maize is low, hence the cost of production will be low. However, cocoyam contains anti-nutritional factors such as oxalates, tannin, saponin, cyanide and phytate, which could be a limitation to its use (Okon et al., 2007). But these limiting factors can be removed by boiling or sundrying (Abdulrashid et al, 2006). Ohaemenyi (1993) reported that Xanthosoma sagittifoilum corms can be cooked and used to some extent in the diets of growing pigs. Esonu (2000) reported that starter broilers could tolerate up to $20 \%$ inclusion level of w i $1 \mathrm{~d}$ vari e gat e d c o c o y a m (Canadiumhortulanum). Anyaegbu et al (2018) reported that fermented cocoyam tubermeal (Xanthosoma sagittifoilum) could be used in the diet of starter and finisher broilers up to $25 \%$ and $100 \%$ respectively without affecting body weight gain, feed intake and feed conversion ratio. Anyaegbu et al. (2016) also reported that finisher broilers chicken group on 15 percent sundried cocoyam tuber meal diet replacing maize recorded the highest body weight gain, better feed intake and feed conversion ratio which were significantly different $(\mathrm{P}<0.05)$ from other groups. There is limited work on the proximate composition and optimum inclusion of cooked cocoyam tubermeal (Xanthosoma sagittifolium) in broiler rations. Hence, the need to investigate the nutritional evaluation of cooked cocoyam tubermeal 


\section{Anyaegbu, Onunkwo, Igwe, Nathaniel and Nkwo}

on growth and carcass characteristics of finisher broiler chickens.

\section{Materials and methods Experimental site}

The experiment was carried out at the poultry unit of the Teaching and research farm of Michael Okpara University of Agriculture, Umudike, Abia State in Nigeria. The area is located at latitude $05^{\circ}$ $29^{\prime}$ North, Longitude $07^{\circ} 32^{\prime}$ East in the rain forest zone in Umuahia, Abia State of Nigeria. This site has an ambient temperature of between $22^{\circ} \mathrm{C}-36^{\circ} \mathrm{C}$ with relative humidity between $50-90 \%$, an annual rainfall of $2177 \mathrm{~mm}$ per annum and an altitude of $123 \mathrm{~m}$ above sea level. It is therefore a humid tropical environment with temperature and relative humidity that are significant in agricultural production (NRCRI, Umudike, 2017).

Procurement and Processing of feed ingredient

$\mathrm{F}$ r e s h c o c o y a $\mathrm{m}$ c o r m s (Xanthosomasagitifolium) Nx 003 were obtained from Amaba in Ikwuano LGA in Abia State. The fresh tannia corms were cut into bits of about $0.2 \mathrm{~cm}$ and put into boiling water for thirty minutes (30 minutes) and later brought out of the cooking drum to cool and later dried with an oven to remove the moisture content. The cooked dried cocoyam was milled to produce cooked cocoyam meal (CCYM) and stored for use. Other feed ingredient like maize, palm kernel cake, brewers' dried grains, blood meal, fish meaL, bone meal, vitamin/mineral/premix, lysine, methionine, salt were bought from Jocan Livestock Services in Umuahia, Abia State.

\section{Chemical analysis of feed ingredients}

Samples of fresh cocoyam corms and cooked cocoyam tubermeal were analysed for proximate composition according to (AOAC, 1990) to determine their nutrient composition from which its metabolisable energy (ME) was estimated (Morgan et al., 1975). All analysis was based on $100 \%$ dry matter. This was done so as to use the value to determine the nutrient composition of the experimental diets which were formulated from them. The components determined were dry matter (DM), Crude protein (CP), Ether extract (EE) and Nitrogen extract (NFE).

\section{Experimental design}

The design of the study was completely randomized design (CRD)

The statistical model is:

$\mathrm{Y}_{\mathrm{ij}}=\mu+\mathrm{T}_{1}+\mathrm{e}_{\mathrm{ij}}$

Where:

$\mathrm{Y}_{\mathrm{ij}}=$ Individual observation

$\mu=$ Population mean

$\mathrm{T}_{1}=$ Treatment effect

$\mathrm{e}_{\mathrm{ij}}=$ Error effect

\section{Anti-nutrients determination}

The test materials fresh and cooked cocoyam corms (Xanthosomasagitifolium) were analysed for the anti-nutrients content such as oxalate, phytic acid, saponins, tannins and cyanide.

\section{Experimental finisher broilers diets}

Five experimental finisher broilers diets were formulated for the feeding trial. Diet 1 (control diet) contained 60\% maize as the major source of energy while diets 2,34 and 5 contained $25 \%, 50 \%, 75 \%$ and $100 \%$ of cooked cocoyam meal to replace maize in the control diet respectively. Other ingredients remained the same in the diets.

\section{Management of experimental finisher} broilers

A total of 150 unsexed Anak finisher broiler chicks at 4 weeks of age (Agrited Broilers) were for the experiment. They were divided into 5 treatment groups of 30 broilers each and each treatment was subdivided into 3 replicates of 10 broilers each. Each replicated was housed in a pen. The broilers were weighed individually at the beginning of the experiment and their average initial 
Growth performance and carcass characteristics of finisher broiler chickens

Table 1: Percentage ingredient composition of finisher broilers experimental diets

\begin{tabular}{lccccc}
\multicolumn{1}{c}{ Ingredients (\%) } & $\begin{array}{c}\text { Diet 1 } \\
\text { (Control) }\end{array}$ & $\begin{array}{c}\text { Diet 2 } \\
\mathbf{2 5 \%} \\
\text { CCYM }\end{array}$ & $\begin{array}{c}\text { Diet 3 } \\
\mathbf{5 0 \%} \\
\text { CCYM }\end{array}$ & $\begin{array}{c}\text { Diet 4 } \\
\mathbf{7 5 \%} \\
\text { CCYM }\end{array}$ & $\begin{array}{c}\text { Diet 5 } \\
\mathbf{1 0 0 \%} \\
\text { CCYM }\end{array}$ \\
\hline Maize & 60.00 & 45.00 & 30.00 & 15.00 & 0.00 \\
CCYM* & - & 15.00 & 30.00 & 45.00 & 60.00 \\
Palm Kernel Cake & 4.20 & 4.20 & 4.20 & 4.20 & 4.20 \\
Brewers' Dried Grains & 8.20 & 8.20 & 8.20 & 8.20 & 8.20 \\
Soyabean meal & 17.00 & 17.00 & 17.00 & 17.00 & 17.00 \\
Fish meal & 3.00 & 3.00 & 3.00 & 3.00 & 3.00 \\
Blood meal & 3.00 & 3.00 & 3.00 & 3.00 & 3.00 \\
Bone meal & 2.40 & 2.40 & 2.40 & 2.40 & 2.40 \\
Vit/mineral Premix** & 0.25 & 0.25 & 0.25 & 0.25 & 0.25 \\
Lysine & 0.10 & 0.10 & 0.10 & 0.10 & 0.10 \\
Methionine & 0.10 & 0.10 & 0.10 & 0.10 & 0.10 \\
Common salt & 0.25 & 0.25 & 0.25 & 0.25 & 0.25 \\
Palm oil & 1.50 & 1.50 & 1.50 & 1.50 & 1.50 \\
Total & 100.00 & 100.00 & 100.00 & 100.00 & 100.00 \\
Calculate nutrient composition of the experimental finisher broiler diets & \\
Crude protein (\%) & 20.47 & 20.27 & 20.07 & 20.05 & 20.00 \\
Crude fibre (\%) & 4.46 & 6.99 & 4.73 & 4.85 & 4.97 \\
Ether extract (\%) & 4.02 & 3.53 & 3.05 & 2.57 & 2.08 \\
Ash (\%) & 2.77 & 3.27 & 2.52 & 4.26 & 4.75 \\
Calcium (\%) & 1.300 & 1.309 & 1.306 & 1.303 & 1.300 \\
Phosphorus (\%) & 0.86 & 0.82 & 0.77 & 0.73 & 0.69 \\
M.E. Kcal/kg & 3002.92 & 3000.82 & 2944.37 & 2900.58 & 2900.00 \\
\hline
\end{tabular}

*cooked cocoyam meal

*To provide per kg diet: Vit. A 5,000,000 i.u.; Vit. D3 1,000,000

weight and sex balanced and weighed weekly thereafter for determination of their growth performance. The broilers were assigned the experimental finisher diets using completely randomized design for 4 weeks. Both water and feed were given ad libitum.

\section{Carcass evaluation}

At the end of the feeding trial, three (3) birds from each treatment were randomly selected, starved of feed but not water for 24 hours, weighed and slaughtered for the determination of the following: internal organ weight (hearts, liver, kidney, spleen, lungs), cut part weights (thigh muscle, wings, back cut, drumstick and breast muscle), abdominal fat and dressed weight. The internal organs weights were expressed as percentage of the live weights.

\section{Data analysis}

The data were subjected to one-way analysis of variance (ANOVA) according to
Snedecor and Cochran (1989), were significant treatment effects were detected from the ANOVA, means were separated using Duncan's New Multiple Range Test (Duncan, 1995).

\section{Results and discussion}

Data on anti-nutrients composition of fresh and cooked tannia (Xanthosoma sagitifolium) were shown in (Table 2). There was significant difference $(\mathrm{P}<0.05)$ in cyanide, Oxalate and tannin content of both the fresh and cooked cocoyam tuber meals. The values obtained from the cooked samples were lower. There was no significant difference $(\mathrm{P}>0.05)$ in phytic acid and saponin content of both the fresh and cooked tannia (Xanthosoma sagitifolium) but numerically the values obtained from the cooked cocoyam tuber meal were lower. Showing that cooking was effective for reducing these anti-nutrients. 
Anyaegbu, Onunkwo, Igwe, Nathaniel and Nkwo

Table 2: Anti -nutrient composition of raw and cooked cocoyam tuber meal (Xanthosoma sagittifolium)

\begin{tabular}{lccc}
\hline Parameters & Fresh Tannia & Cooked tannia & SEM \\
\hline Cyanide $(\mathrm{mgCN} / \mathrm{g})$ & $0.29^{\mathrm{a}}$ & $0.21^{\mathrm{b}}$ & 0.73 \\
Phytic acid (\%) & $57.23^{\mathrm{a}}$ & $56.09^{\mathrm{b}}$ & 0.76 \\
Oxalate (\%) & $17.34^{\mathrm{a}}$ & $11.53^{\mathrm{b}}$ & 0.83 \\
Tannin (\%) & $1.83^{\mathrm{a}}$ & $0.46^{\mathrm{b}}$ & 1.02 \\
Saponin (\%) & $24.10^{\mathrm{a}}$ & $22.02^{\mathrm{b}}$ & 1.71 \\
\hline a,b & &
\end{tabular}

${ }_{\mathrm{a}, \mathrm{b}}$ Means within the same row with different superscripts are significantly different $(\mathrm{P}<0.05)$

Data on the proximate composition of fresh and cooked cocoyam tuber meal (Xanthosoma sagittifolium) were shown in (Table 3). There was significant difference $(\mathrm{P}<0.05)$ in the percentage moisture and crude fiber of both the fresh and cooked cocoyam meal. Cooking and drying reduces the high moisture and crude fiber content to a tolerable level. There were no significant differences $(\mathrm{P}>0.05)$ in the percent ash, crude protein, ether extract, and NFE of both the fresh and cooked cocoyam tubers, showing that cooking did not affect the proximate content of the cocoyam.

Table 3: Proximate composition of fresh and cooked cocoyam tuber (Xanthosoma sagitifolium)

\begin{tabular}{lccc}
\hline Parameters & $\begin{array}{c}\text { Fresh cocoyam } \\
\text { tuber }\end{array}$ & $\begin{array}{c}\text { Cooked cocoyam } \\
\text { tuber }\end{array}$ & SEM \\
\hline Moisture (\%) & $58.05^{\mathrm{b}}$ & $13.11^{\mathrm{a}}$ & 4.92 \\
Ash (\%) & 4.80 & 2.60 & 0.78 \\
Crude protein (\%) & 5.43 & 3.90 & 0.54 \\
Crude fibre (\%) & $9.45^{\mathrm{a}}$ & $4.74^{\mathrm{b}}$ & 1.67 \\
Ether extract (\%) & $2.40^{\mathrm{b}}$ & $1.85^{\mathrm{a}}$ & 0.09 \\
NFE (\%) & 39.82 & 70.13 & 10.72 \\
\hline
\end{tabular}

$\overline{\mathrm{a}, \mathrm{b}}$ Means within the same row with different superscripts are significantly different $(\mathrm{P}<0.05)$

Table 4: Proximate composition of experimental finisher broiler diets

\begin{tabular}{lcccccc}
\hline Parameters & $\begin{array}{c}\text { Diet 1 } \\
\text { (Control) }\end{array}$ & $\begin{array}{c}\text { Diet 2 } \\
\mathbf{2 5 \%} \\
\text { CCYM }\end{array}$ & $\begin{array}{c}\text { Diet 3 } \\
\mathbf{5 0 \%} \\
\text { CCYM }\end{array}$ & $\begin{array}{c}\text { Diet 4 } \\
\mathbf{7 5 \%} \\
\text { CCYM }\end{array}$ & $\begin{array}{c}\text { Diet 5 } \\
\mathbf{1 0 0 \%} \\
\text { CCYM }\end{array}$ & SEM \\
\hline Moisture (\%) & 9.74 & 11.84 & 12.13 & 12.70 & 13.50 & 0.56 \\
Ash (\%) & 6.74 & 9.00 & 9.69 & 10.50 & 11.48 & 0.72 \\
Crude protein (\%) & 20.38 & 18.75 & 17.50 & 16.75 & 16.50 & 0.64 \\
Crude fibre (\%) & 6.10 & 8.80 & 9.80 & 11.50 & 12.90 & 1.04 \\
Ether extract (\%) & 3.80 & 3.38 & 3.00 & 2.80 & 2.65 & 0.19 \\
NFE (\%) & 53.24 & 48.23 & 47.88 & 45.75 & 42.95 & 1.51 \\
\hline
\end{tabular}

\section{Feed intake}

The average feed intake of the finisher broilers were $130 \mathrm{~g}, 129.00 \mathrm{~g}, 127.00 \mathrm{~g}$, $128.00 \mathrm{~g}$ and $110.00 \mathrm{~g}$ respectively for the control group diet 2, 34 and 5. The feed intake of the finisher broilers on diet 2, 3 and 4 were similar and compared favourably with those on the control diet and significantly different $(\mathrm{P}<0.05)$ from those on diet $5(100 \%$ CCYM). The finisher broiler group on diet $5(100 \%$ CCYM $)$ recorded the lowest feed intake of $110.00 \mathrm{~g}$. This could be due to the dustiness of the feed because of high content of cooked cum dried cocoyam tuber meal.

\section{Body weight gain}

The body weight gain of the finisher broilers were $1.40 \mathrm{~kg}, 1.33,0.859 \mathrm{~kg}$, $0.952 \mathrm{~kg}$ and $0.780 \mathrm{~kg}$ for the control group (Diet 1). 2,3, 4 and 5 respectively. The body weight gain of the finisher broilers on diet $2(25 \%)$ cooked cocoyam meal compared 


\section{Growth performance and carcass characteristics of finisher broiler chickens}

favourably with the control group and was significantly $(\mathrm{P}<0.05)$ higher than those on other diets. It appeared that the finisher broilers could not tolerate high levels of cooked cocoyam tuber meal in their diets. This could be due to the dustiness of the diets.

\section{Feed conversion ratio}

The feed conversion ratio of the finisher broilers on the control diet and diet $2(25 \%$ CCYM) were similar and significantly $(\mathrm{P}<0.05)$ higher than those on diet 3, 4 and 5 respectively (Table 5).

Table 5: Effects of the experimental diets on the performance of finisher broilers

\begin{tabular}{lcccccc}
\hline Parameters & $\begin{array}{c}\text { Diet 1 } \\
\text { (Control) }\end{array}$ & $\begin{array}{c}\text { Diet 2 } \\
\mathbf{2 5 \%} \\
\text { CCYM }\end{array}$ & $\begin{array}{c}\text { Diet 3 } \\
\mathbf{5 0 \%} \\
\text { CCYM }\end{array}$ & $\begin{array}{c}\text { Diet 4 } \\
\mathbf{7 5 \%} \\
\text { CCYM }\end{array}$ & $\begin{array}{c}\text { Diet 5 } \\
\mathbf{1 0 0}\end{array}$ & CCYM \\
\hline Initial Body wt. gain (g) & 900.00 & 869.37 & 830.27 & 597.20 & 519.70 & 69.09 \\
Final body wt. gain (Kg) & $2.30^{\mathrm{a}}$ & $2.20^{\mathrm{a}}$ & $1.69^{\mathrm{b}}$ & $1.55^{\mathrm{c}}$ & $1.30^{\mathrm{c}}$ & 0.15 \\
Body wt. gain (Kg) & $1.40^{\mathrm{a}}$ & $1.33^{\mathrm{a}}$ & $0.859^{\mathrm{b}}$ & $0.952^{\mathrm{b}}$ & $0.780^{\mathrm{b}}$ & 0.10 \\
Daily body wt. gain (g) & $50.00^{\mathrm{a}}$ & $47.50^{\mathrm{a}}$ & $30.68^{\mathrm{b}}$ & $34.00^{\mathrm{b}}$ & $27.86^{\mathrm{b}}$ & 2.06 \\
Daily feed intake (g) & $130.00^{\mathrm{a}}$ & $129.00^{\mathrm{a}}$ & $127.00^{\mathrm{a}}$ & $128.00^{\mathrm{a}}$ & $110.00^{\mathrm{b}}$ & 3.34 \\
Feed conversion ratio & $2.60^{\mathrm{a}}$ & $2.72^{\mathrm{a}}$ & $4.14^{\mathrm{b}}$ & $3.77^{\mathrm{b}}$ & $3.95^{\mathrm{b}}$ & 0.16 \\
\hline
\end{tabular}

$\overline{\mathrm{a}, \mathrm{b}, \mathrm{c}}$ Means within the same row with different superscripts are significantly different $(\mathrm{P}<0.05)$

Percentage cut part weight of experimental finisher broiler

The percentage cut part weight of the experimental finisher broilers were shown in Table 6. The finisher broilers on diet 2 (25\% CCYM) recorded the highest breast muscle which was significantly different from other groups. There were no significant different $(\mathrm{P}>0.05)$ on percent back cut. Drumstick, head, shank, thigh, neck and wings of the finisher broilers on all the diets.

Table 6: Percentage cut part weights of the experimental finisher broilers

\begin{tabular}{lcccccc}
\hline Parameters & Diet 1 & Diet 2 & Diet 3 & Diet 4 & Diet 5 & SEM \\
\hline Back cut & 13.03 & 12.25 & 15.73 & 14.63 & 14.36 & 0.55 \\
Breast muscle & $15.76^{\mathrm{c}}$ & $18.58^{\mathrm{a}}$ & $17.11^{\mathrm{b}}$ & $16.74^{\mathrm{c}}$ & $16.68^{\mathrm{c}}$ & 0.40 \\
Drumstick & 9.64 & 10.00 & 10.52 & 9.36 & 9.32 & 0.20 \\
Head & 2.86 & 3.47 & 3.83 & 3.62 & 4.28 & 0.21 \\
Shank & 4.76 & 5.14 & 5.52 & 4.12 & 4.74 & 0.21 \\
Thigh & 10.53 & 10.00 & 9.70 & 9.69 & 10.28 & 0.15 \\
Neck & 3.63 & 3.61 & 4.59 & 3.63 & 4.13 & 0.17 \\
Wing & 9.20 & 9.64 & 9.63 & 8.89 & 9.56 & 0.13 \\
\hline a,b,c Means within the same row with different superscripts are significantly different $(\mathrm{P}<0.05)$ & \multicolumn{5}{c}{}
\end{tabular}

\section{Internal organ weights}

The percent internal organ weights of the experimental finisher broilers were shown in Table 7.

The weight of the organs (liver, gizzard, heart, kidney, spleen, large intestine, small intestine, proventiculus, lungs, abdominal fat of the birds in all the groups were not affected by the treatments $(\mathrm{P}<0.05)$, the birds in diets $2(25 \%$ CCYM and $3(50 \%$ CCYM) accumulated significantly $(\mathrm{P}<0.05)$ more abdominal fat than the others indicating higher efficiency of the birds in converting the carbohydrates of the diets into fat.

\section{Percentage dressed weights}

Percentage dressed weight of the experimental finisher broilers on cooked cocoyam based diets is shown in Table 8 . There was no significant difference $(\mathrm{P}<0.05)$ in percentage dressed weight of the experimental finisher broilers on cooked cocoyam based diets in all the treatments. 
Anyaegbu, Onunkwo, Igwe, Nathaniel and Nkwo

Table 7: Percentage Internal organs weights of the experimental finisher broilers

\begin{tabular}{lcccccc}
\hline Parameters & $\begin{array}{c}\text { Diet 1 } \\
\text { (Control) }\end{array}$ & $\begin{array}{c}\text { Diet 2 } \\
\mathbf{2 5 \%} \\
\text { CCYM }\end{array}$ & $\begin{array}{c}\text { Diet 3 } \\
\mathbf{5 0 \%} \\
\text { CCYM }\end{array}$ & $\begin{array}{c}\text { Diet 4 } \\
\mathbf{7 5 \%} \\
\text { CCYM }\end{array}$ & $\begin{array}{c}\text { Diet 5 } \\
\mathbf{1 0 0 \%} \\
\text { CCYM }\end{array}$ & SEM \\
\hline Live weight (Kg) & $1.65^{\mathrm{a}}$ & $1.04^{\mathrm{b}}$ & $0.90^{\mathrm{c}}$ & $0.98^{\mathrm{c}}$ & $0.76^{\mathrm{c}}$ & 0.14 \\
Dressed wt. (Kg) & $1.08^{\mathrm{a}}$ & $0.70^{\mathrm{b}}$ & $0.58^{\mathrm{b}}$ & $0.65^{\mathrm{b}}$ & $0.66^{\mathrm{b}}$ & 0.08 \\
Percent dressed wt & $65.45^{\mathrm{b}}$ & $67.31^{\mathrm{b}}$ & $64.44^{\mathrm{b}}$ & $66.33^{\mathrm{b}}$ & $86.84^{\mathrm{a}}$ & 3.77 \\
Liver & 3.22 & 3.10 & 3.03 & 3.49 & 3.51 & 0.09 \\
Gizzard & 2.26 & 2.05 & 3.07 & 3.09 & 2.52 & 0.26 \\
Heart (\%) & 0.59 & 0.63 & 0.68 & 0.66 & 0.61 & 0.02 \\
Spleen (\%) & 0.18 & 0.18 & 0.19 & 0.16 & 0.20 & 0.01 \\
Abdominal fat (\%) & $0.71^{\mathrm{c}}$ & $1.45 \mathrm{~b}$ & $1.90^{\mathrm{a}}$ & $1.06^{\mathrm{ab}}$ & $1.45^{\mathrm{b}}$ & 0.18 \\
Large intestine (\%) & 1.91 & 1.58 & 2.17 & 2.24 & 3.05 & 0.22 \\
Small intestine (\%) & 5.19 & 3.89 & 4.78 & 4.85 & 5.46 & 0.24 \\
Proventiculus (\%) & 0.72 & 0.67 & 0.79 & 0.85 & 0.79 & 0.03 \\
Kidney (\%) & 0.52 & 0.67 & 0.49 & 0.88 & 0.82 & 0.07 \\
Lungs (\%) & 0.89 & 0.63 & 0.73 & 0.77 & 0.81 & 0.04 \\
Crop (\%) & 0.58 & 0.49 & 0.48 & 0.61 & 0.61 & 0.03 \\
\hline
\end{tabular}

$\overline{a, b, c}$ Means within the same row with different superscripts are significantly different $(\mathrm{P}<0.05)$

Table 8: Percentage dressed weight

\begin{tabular}{lcccccc}
\hline Parameters & $\begin{array}{c}\text { Diet 1 } \\
\text { (Control) }\end{array}$ & $\begin{array}{c}\text { Diet 2 } \\
\mathbf{2 5 \%}\end{array}$ & $\begin{array}{c}\text { Diet 3 } \\
\mathbf{5 0 \%}\end{array}$ & $\begin{array}{c}\text { Diet 4 } \\
\mathbf{7 5 \%}\end{array}$ & $\begin{array}{c}\text { Diet 5 } \\
\mathbf{1 0 0 \%}\end{array}$ & SEM \\
& & CCYM & CCYM & CCYM & CCYM & \\
\hline Dressed wt (kg) & 1.08 & 0.70 & 0.58 & 0.65 & 0.66 & 0.08 \\
Dressed (\%) & 65.45 & 67.31 & 64.44 & 66.33 & 86.84 & 3.77 \\
\hline
\end{tabular}

Means within the same row with different superscripts are significantly different $(\mathrm{P}<0.05)$

Table 9: Economics of finisher broiler fed experimental diets

\begin{tabular}{lcccccc}
\hline Parameters & $\begin{array}{c}\text { Diet 1 } \\
\text { (Control) }\end{array}$ & $\begin{array}{c}\text { Diet 2 } \\
\mathbf{2 5 \%}\end{array}$ & $\begin{array}{c}\text { Diet 3 } \\
\mathbf{5 0 \%}\end{array}$ & $\begin{array}{c}\text { Diet 4 } \\
\mathbf{7 5 \%}\end{array}$ & $\begin{array}{c}\text { Diet 5 } \\
\mathbf{1 0 0 \%}\end{array}$ & SEM \\
& & CCYM & CCYM & CCYM & CCYM & \\
\hline Cost $/$ Kg feed & $173.66^{\mathrm{c}}$ & $147.86^{\mathrm{c}}$ & $122.06^{\mathrm{ab}}$ & $96.26^{\mathrm{b}}$ & $70.44^{\mathrm{a}}$ & 17.49 \\
Cost of production/Kg broiler & $411.82^{\mathrm{c}}$ & $432.93^{\mathrm{ab}}$ & $588.28^{\mathrm{c}}$ & $381.20^{\mathrm{b}}$ & $356.72^{\mathrm{a}}$ & 36.36 \\
\hline $\mathrm{a}, \mathrm{b}, \mathrm{c}$ Means within the same row with different superscripts are significantly different $(\mathrm{P}<0.05)$ & &
\end{tabular}

Economics of finisher broiler fed experimental diets

In the finisher feeding trial, the cost of production per $\mathrm{kg}$ of cocoyam based finisher broiler diet was cheapest for diet $5(100 \%$ CCYM) (N70.44) while the costliest was those on diet 1 (maize based diet) (N173.66). The cost of production per $\mathrm{kg}$ broiler was cheapest for diet $5(100 \%$ CCYM) (N356.72) and the costliest was those on diet $3(50 \%$ CCYM) (N588.28).

\section{Discussion}

The result of the trials in respect to the antinutrient content of both raw and cooked cocoyam tuber meal showed that the raw cocoyam tuber contained cyanide up to 1.83 $(\mathrm{mgCN} / \mathrm{g})$ but cooking reduced it to 0.46 $(\mathrm{mgCN} / \mathrm{g})$ which was tolerable to the broiler chicken. Other anti-nutrient contents like tannis, oxalate were also reduced by cooking. (Agwunobi et al., 2002) recorded that cooking and sundried cocoyam reduces their oxalate, tannin and saponin contents, the tannin content of the cocoyam tubers were also reduced from $1.83 \%$ to $0.48 \%$ by boiling. According to (Onu et al, 2004) boiling and/or supplementation with oil are common acceptable means of detoxification among 
Nigerians.

\section{Performance offinisher broilers}

The feed intake of the finisher broilers on diets 2, 3 and4 were similar and compared favourably with those on the control diet. The finisher group on diet $5(100 \%$ CCYM) recorded the lowest feed intake possibly because of the dustiness of the diet and the anti nutrients. The body weight gain of the finisher broilers on diet $2(25 \%$ CCYM $)$ compared favourably with the control group. It appeared that finisher broilers could not tolerate high levels of cooked cocoyam meal. This shows that cooking is an effective processing technique for cocoyam tubers for finisher broilers (Onu et al, 2004). The cost of feed per kg decreases linearly $(\mathrm{P}>0.05)$ with increase in the level of CCYM. This was due to reduced cost of cocoyam compared to maize which has a high economic implication in the use of these diets. The lower cost of feed per $\mathrm{kg}$ in finisher broilers was achieved with the diets $5(100 \%$ CCYM $)$ producing at N70.44per $\mathrm{kg}$ weight gain respectively. The cost of production decreases with increase in the level of CCYM in finisher phase. The lowest cost of producing $/ \mathrm{kg}$ broiler was observed in $100 \%$ level of CCYM and the highest cost of production $/ \mathrm{kg}$ broiler was N588.28 in diets $3(50 \%$ CCYM). This was due to reduced cost of feed consumed which indicates economic implications in the use of cooked sundried tannia. The values on the feed conversion ratio increases with increase in the levels of CCYM in the finisher phase, thus indicating that the higher the levels of CCYM, the less the utilization of the diets. This may be attributed to the inability of the birds to extract required nutrients from the feed because of the anti-nutritional factors and dustiness of the feed

\section{Conclusion}

It was concluded that 30 minutes cooking of cocoyam tubers (Xanthosoma sagittifolium) was quite an effective method of processing cocoyam tuber meal for use in finisher broilers because cooking reduces the anti-nutrients in cocoyam tubers to a tolerable level for broiler chicken as illustrated in this study. It was concluded that cooked cocoyam tuber meal (Xanthosoma sagittifolium) could be used in the diet of finisher broilers up to $25 \%$ without affecting body weight gain, feed intake, feed conversion ratio and carcass characteristics as indicated in this study.

\section{Recommendations}

It is therefore recommended that large scale $\mathrm{p} \mathrm{rod} \mathrm{u} \mathrm{c} \mathrm{t} \mathrm{i} \mathrm{o} \mathrm{n}$ of c o c o y a m (Xanthosomasagittifolium) for poultry feeding be encouraged so as to reduce the pressure of demand on maize. This may help to reduce the cost of poultry production and hence the cost of poultry products, eggs, and poultry meat.

\section{References}

Abdulrashidi, M., Agwunobi, L. N., Akpa, G. N. and Adeyinka, E. D. 2006. The performance of finisher broiler on varying level of Taro cocoyam meal. Proceedings of the $13^{\text {th }}$ Annual Conference of Nigerian Society for Animal Production NSAP Kano, March, $15^{\text {th }} .285-$ 289.

Adejinmi, O. O., Adejumo, J. O. and Adeleya, I. O. A. 2000 . Replacement value of fishmeal with soldier fly larvae meal in broiler diets. Nigerian Poultry Science Journal. 1:52-60.

Adeola, O. and Olukosi, O. A. 2009. Opportunities and challenges in the use of alternative feedstuffs in poultry production. Proceedings of the $3^{\text {rd }}$ Nigeria International Poultry Summit 22 - 26 February 2009. Abeokuta, ogun State, 
Nigeria. P. $44-54$.

Agwunobi, L. N. and Essien, E. A. 1995. The performance of broiler chickens on sweet potato diets. Journal of Agricultural Technology. 3(1): NBTE pp. $69-$ 74.

Anyaegbu, B. C. Ogbonna, A. C., Adedokun, O. O. and Onunkwo, D. N. 2018a. Dietary evaluation of fermented cocoyam tubermeal (Xanthosoma sagitifolium) as energy source in place of maize in broiler chicken production. Nigeria Journal of Animal Production 2018, 45(2): 114 - 123. (C) Nigerian Society for Animal Production.

Anyaegbu, B. C., Onunkwo, D. N., Nosike, R. J. and Orji, M. C. 2017. Growth performance of starter broilers fed processed $\begin{array}{lllllll}\text { c } & 0 & \mathrm{c} & \mathrm{o} & \mathrm{y} & \mathrm{a} & \mathrm{m}\end{array}$ (Xanthosomasagittifolium) as energy source in place of maize. Nig. J. Anim. Prod. 44(3): 230 237.

Anyaegbu, B. C., Onunkwo, D. N., Ogbonna, A. C. and Uzoigwe, $O$. 2018b. Nutritional evaluation of fermented cocoyam tubermeal (Xanthosoma sagitifolium) as energy source in place of maize in starter broiler production. Nig. J. Anim Prod. 45(3): 260 - 267. (C) Nigerian Society for Animal Production.

Anyaegbu, B. C., Orgi, M. C., Ebuzor, C. A., Okwandu, P. and Adedoku, O. O. 2016. Replacement value of maize with different levels of $\mathrm{s} \mathrm{u} \mathrm{n} \mathrm{d} \mathrm{ri} \mathrm{e} \mathrm{d} \mathrm{c} \mathrm{o} \mathrm{c} \mathrm{o} \mathrm{y} \mathrm{a} \mathrm{m}$ (Xanthosomasagitifolium) as energy source on finisher broilers performance. Proceedings of the $21^{\text {st }}$ Annual Conference of Animal
Science Association of Nigeria. 18 $-22^{\text {nd }}$ September, Port Harcourt.

AOAC 1990. Official methods of Analysis. $15^{\text {th }}$ edn. Arlington V. A. Association of official analytical chemists.

Bello, A. J. N. 1976. Food and Nutrition in Practice, Macmillan Education Ltd, London, P. 32.

Duncan, D. B. 1955. Multiple range and multiple F. test. Biometrics. 11: 142.

Esonu, B. O. 2000. Effect of dietary cooked wild variegated cocoyam (Caladiumhortulanum) on the performance of broiler chickens. Tropical Agric. 22(4): 269-271.

Etim, N. N., Enyenihi, G. E., Williams, E. M., Udo, D. M. and Effiong, E. A. E. 2013. Haematological parameters. Indicators of the physiological status of farm animals. British Journal of Science. 10(1): $350-356$.

FAO 2004. Food and Agricultural Organization Statistics Database; Food and Agriculture, Italy: int'1 Org. of the United Rome.

Gohl, B. O. 1975. Tropical feeds information summaries and nutritive value. Food and Agricultural organization of United Nations, Rome 25, p. 31.

Jain, N. L. 1993 Essentials of veterinary haematology. Philadephia. Lea et Fabiger.

Mitruka, B. M. and Rawn, H. M. 1997. Clinical biochemical and haematological reference values in normal experimental animal. Masson Publishing USA Inc. New York.

Morgan, D. J., Cole, D. J. A., Lewis, D. 1975. Energy value in pig nutrition. The relationship between digestible energy, metabolizable 
energy and the total digestible nutrition value of a wide range of feedstuffs. J. Agric. Sci. Cambridge. 84: $7-17$.

Mwenye, O. J. 2009. Genetic diversity analysis and nutritional assessment of cocoyam genotypes in Malawi. M.Sc. Project. Department of Plant Science, University of Free Bloemfontein, South Africa.

NRCRI, 2017. Agro-metrologic unit, National Root Crop Research Institute, Umudike, Umuahia, Nigeria.

Obasi, P. C. 2009. The trade-offs between agrofuels production and food prices. Proceedings of the International Conference on Global food crisis. Federal University of Technology, Owerri, Nigeria. April 19-24, 2009. P270274.

Ohaemenyi, C. F. 1993. A study of the corm of Xanthosoma sagittifolium (cocoyam) as a substitute for maize in the diet of young growing pigs. B.Sc. Thesis. Fed. Uni of Tech. Owerri, Nigeria.

Oke, M. O. and Bolarinwa, I. F. 2012. Effect of fermentation on physiochemical properties and oxalate content of cocoyam (Colocasia esculenta) flour. International scholarly research Network ISRN Agronomy, 2012, Article ID 978709.

Okon, B. I., Obi, M. B., Ayuk, A. A. 2007. Performance of quail (Cortunix japonica) fed graded levels of boiled sundried taro cocoyam (Colocasia esculenta) as replacement to maize. Medwell Outline Agric. J. 216: 654-657.
Omeje, S. I. 1999. Issues in animal science, a compendium of ideas, facts and methods in the science and technology of animal production. RayKennedy Scientific Publishing, Enugu, Pp. 83-100.

Onu, P.U., Madubuike, F. U., Uchewa, E. N., Otuma, M. O. and Asogwu, M. O. 2004. Effect of cooking on the nutritive value of wild cocoyam (Caladium bicolor) in broiler starter ration. Proc. $9^{\text {th }}$ Annual Conf. Animal Sci. AGS of Nigeria $(A S A N)$. Ebonyi State University, Abakaliki. $42-4$.

Onunkwo, D. N., Anyaegbu, B. C., Odukwe, C. N., Amahiri, C. and Ogu, C. M. 2016. Replacement value of maize with sundried cocoyam (Xanthosoma sagittifolium) as energy source in the performance of starter broilers. InternationalResearch Journal of Agriculture and Aquatic Sciences. 3(1): 134 - 128. ISSN 2411 - 2895. www.sci-africpublishers.org.

Onwumere, I. C. 1982. The tropical tuber crops utilization, economics and future prospects of cocoyams. ELBS Edition. John Wiley and Sons Ltd. Pp. 20.

Tewe, O. O. 1997. Sustainability and development paradigm from Nigeria's livestock Ind. Inaugural Lecture delivered on behalf of Faculty of Agriculture and Forestry, University of Ibadan. pg 50.

Received: $9^{\text {th }}$ August, 2019 Accepted: $19^{\text {th }}$ December, 2019 